\title{
Evaluasi Kecukupan Nutrisi Sapi Bali Jantan Muda di BPT-HMT Serading Kabupaten Sumbawa
}

\section{(Evaluation of Nutrition Adequacy of Young Male Bali Cow in BPT-HMT Serading, Sumbawa District)}

\author{
Muhamad Amin ${ }^{1)}$, Oscar Yanuarianto ${ }^{1)}$, Sofyan Damrah Hasan ${ }^{1)}$ \\ Syamsul Hidayat Dilaga ${ }^{1)}$, Suhubdy ${ }^{1)}$, Husni $^{2}{ }^{2}$ \\ ${ }^{1)}$ Program Studi Peternakan, Fakultas Peternakan, Universitasa Mataram \\ Jl. Majapahit 62 Mataram 83125 NTB; Telp. (0370)633603; Fax (0370) 640592 \\ ${ }^{2}$ Program Studi Peternakan, Fakultas Teknobiologi, Universitas Teknologi Sumbawa-UTS \\ Jl. Olat Maras, Batu Alang Moyo Hulu, Sumbawa 84371 NTB; Telp. (0371)262909 \\ E-mail : muhamadamin686@yahoo.co.id
}

Diterima : 02 April 2021/Disetujui : 18 Mei 2021

\begin{abstract}
ABSTRAK
Studi dengan tujuan mengevaluasi kecukupan nutrisi sapi jantan muda Bali dilakukan selama 3 bulan sejak Juni hingga September 2020 di BPT-HMT Serading, Kabupaten Sumbawa. Pengamatan dilakukan terhadap sepuluh ekor sapi bali jantan muda dengan berat badan awal rata-rata $114 \mathrm{~kg}$. Variabel yang diamati termasuk jenis, kualitas dan konsumsi pakan, dan kenaikan berat badan harian. Data yang diperoleh dalam penelitian ini dianalisis secara deskriptif. Hasil penelitian menunjukkan bahwa BPTHMT Serading menerapkan sistem pemeliharaan semi intensif pada sapi jantan muda Bali dengan memberi mereka makan rumput raja, lamtoro, sedotan jagung, dan gamal. Selain ditulis, ternak juga dilepaskan di padang rumput bintang. Konsumsi BK adalah 2,56, PK adalah 0,253 dan TDN adalah $1,53 \mathrm{~kg} / \mathrm{kepala} /$ hari, sedangkan kebutuhan BK adalah 3,19, PK adalah 0,331 dan TDN adalah 1,92 kg / kepala / hari. Kenaikan berat badan harian $0,08 \mathrm{~kg} / \mathrm{kepala} /$ hari. Berdasarkan hasil penelitian, dapat disimpulkan bahwa jumlah pakan yang dikonsumsi tidak mencukupi untuk sapi jantan muda Bali. Dianjurkan untuk memperhatikan kualitas dan kuantitas pakan yang diberikan kepada ternak, untuk menerapkan teknologi silase dan fermentasi pada cadangan pakan stok di musim kemarau.
\end{abstract}

Kata kunci : Sapi Bali Jantan Muda, Konsumsi Pakan, Kenaikan Berat Badan Harian, Kecukupan Nutrisi, Sumbawa. 


\begin{abstract}
A study with the aim of evaluating the nutritional adequacy of young Bali bulls was conducted for 3 months from June to September 2020 at BPT-HMT Serading, Sumbawa Regency. Observations were made on ten young male Bali cattle with an average initial body weight of $114 \mathrm{~kg}$. The observed variables included type, quality and feed consumption, and daily body weight gain. The data obtained in this study were analyzed descriptively. The results showed that BPT-HMT Serading applied a semi-intensive maintenance system on young Bali bulls by feeding them king grass, lamtoro, corn straw, and gamal. In addition to being penned, livestock are also released in the star meadow. The consumption of dry matter was 2.56, CP was 0.253 and TDN was $1.53 \mathrm{~kg} /$ head / day, while the need for DM was 3.19, CP was 0.331 and TDN was $1.92 \mathrm{~kg} /$ head / day. Daily body weight gain was of $0.08 \mathrm{~kg} /$ head / day. Based on the results of the study, it can be concluded that the amount of feed consumed is not sufficient for young Bali bulls. It is advisable to pay attention to the quality and quantity of feed given to livestock, to apply silage and fermentation technology to stock feed reserves in the dry season.
\end{abstract}

Keywords: young Bali bull, feed consumption, daily body weight gain, nutritional adequacy, Sumbawa.

\section{PENDAHULUAN}

Penyebab utama rendahnya produktivitas dari ternak sapihan sapi Bali adalah pola pemeliharaan serta manajemen ternak yang rendah dan kurang terarah, dimana peternak belum memperhatikan mutu pakan, tata cara pemeliharaan, perkandangan dan penyakit sehingga pertumbuhan ternak pada umur pertumbuhan kurang optimum, menyebabkan sapihan sapi Bali betina dan jantan yang diharapkan mampu menjadi bibit indukan dan pejantan yang unggul menjadi kurang optimal. Pemeliharaan sapihan sapi dengan baik menghasilkan produktifitas sapi yang tinggi, termasuk sapihan sapi betina ataupun jantan. Untuk mengetahui potensi genetik yang dimiliki oleh sapihan sapi dilakukan pemeliharaan secara intensif.
Ada tiga hal yang perlu diperhatikan dalam pemeliharaan ternak yaitu pembibitan, pakan, dan manajemen (Santosa, 2002). Pakan memiliki pengaruh yang paling besar yaitu sekitar 60\%. Hal ini menunjukkan bahwa walaupun potensi genetik ternak tinggi, namun apabalia pemberian pakan tidak memenuhi maka produksi yang tinggi tidak akan tercapai. Selain itu, pakan juga merupakan komponen produksi dengan biaya yang besar, yaitu dapat mencapai $60-80 \%$ dari total biaya produksi.

Pemenuhan kebutuhan ternak akan nutrisi yang cukup dan seimbang penting diperhatikan, karena hal ini merupakan salah satu faktor yang berpengaruh besar terhadap pertumbuhan dan produksi ternak. Potensi genetik ternak yang tinggi 
apabila tidak diimbangi dengan pemberian pakan yang memenuhi kebutuhan nutriennya, maka produksi yang tinggi tidak akan tercapai. Kondisi ini nantinya dikhawatirkan akan memberikan respon yang kurang menguntungkan terhadap performan pertumbuhan ternak, respon ternak terhadap manipulasi yang diberikan juga ikut menentukan hasil dari pejantan dan indukan yang berkualitas baik.

Balai Pembibitan Ternak dan Hijauan Makanan Ternak (BPTHMT) Serading merupakan salah satu lembaga di bawah Dinas Peternakan dan Kesehatan Hewan Provinsi Nusa Tenggara Barat yang mengelola sistem pembibitan ternak dan pemeliharaan hijauan makanan ternak. Lokasi ini terletak khususnya di Desa Serading Kecamatan Moyo Hilir Kabupaten Sumbawa. BPTHMT memiliki luas sekitar 42,52 Ha dan tempat lokasi padang penggembalaan untuk melepas ternak. Jumlah ternak yang ada di BPT-HMT Serading sekitar 184 ekor, yaitu 39 ekor betina dewasa, 5 ekor jantan dewasa, 54 ekor betina muda dan 55 pedet lepas sapih. Sedangkan jumlah sapi Bali calon pejantan yang dipelihara sampai dengan bulan September 2020 adalah sebanyak 31 ekor. Sebagai salah satu pusat pembibitan ternak, BPT-HMT Serading mempunyai tugas yang cukup penting sebagai salah satu tempat pembibitan sapi Bali yang dapat menghasilkan bakalan pejantan dan indukan yang berkualitas.

Permasalahan utama dalam usaha peternakan adalah ketersediaan pakan, hal inilah yang juga dialami oleh BPT-HMT Serading. Pada kondisi tertentu ketersediaan hijauan pakan sangat terbatas sehingga kualitas dan kuantitas hijuaan pakan yang diberikan juga berfluktuatif, tentunya hal ini juga berpengaruh terhadap produktifitas ternak yang dipelihara.

Potensi genetik sapi Bali harus ditingkatkan dan kemudian diikuti dengan pemberian pakan yang sesuai dengan kebutuhannya agar potensi genetiknya mampu berkembang secara maksimal. Pemeliharaan secara intensif dapat memudahkan untuk mengetahui potensi genetik yang dimiliki oleh ternak. Dengan demikian pemeliharaan secara intensif dapat memudahkan peternak untuk mengawasi peternakan. Pemberian pakan yang sesuai dengan kebutuhan ternak hanya dapat dilakukan apabila ternak dipelihara secara intensif atau dikandangkan.

Berdasarkan pemikiran di atas maka perlu dilakukan suatu penelitian yang bertujuan untuk mengevaluasi kecukupan nutrisi sapi Bali jantan muda sebagai calon pejantan yang dipelihara di BPT-HMT Serading Kabupaten Sumbawa. Informasi yang diperoleh dalam penelitian ini 
diharapkan dapat membantu meningkatkan manajemen pemeliharaan sapi Bali calon pejantan terutama dalam hal pemenuhan nutrisi, sehingga diperoleh sapi-sapi pejantan unggul.

\section{MATERI DAN METODE Waktu dan Tempat}

Penelitian telah dilaksanakan selama tiga bulan, mulai dari tanggal 15 Juni sampai dengan 15 September 2020, bertempat di BPT-HMT Serading Kabupaten Sumbawa. Analisis kandungan nutrisi bahan pakan dilakukan di Laboratorium Ilmu Nutrisi dan Makanan Ternak Fakultas Peternakan Universitas Mataram.

\section{Materi}

Peralatan yang digunakan pada penelitian ini adalah timbangan ternak, timbangan pakan, parang, ember, kamera dan alat tulis. Materi yang digunakan adalah sepuluh ekor sapi Bali jantan muda dengan bobot badan rata-rata $114 \mathrm{~kg}$, dan pakan (rumput raja, rumput bintang, jerami jagung, lamtoro dan gamal).

\section{Metode}

Sepuluh ekor sapi Bali jantan muda yang telah diketahui bobot badannya ditempatkan dalam kandang kelompok yang telah dilengkapi dengan tempat pakan dan air minum. Pemberian pakan di dalam kandang dilakukan 2 kali sehari. Selain pakan diberikan di dalam kandang, ternak juga dilepas untuk merumput secara bebas di padang penggembalaan selama 2-3 jam. Penimbangan ternak dilakukan 4 kali, yakni pada awal bulan pertama, akhir bulan pertama, akhir bulan kedua dan akhir bulan ketiga penelitian. Penimbangan dilakukan pada waktu yang sama yaitu pagi hari sebelum ternak diberi pakan. Selain itu dilakukan pengambilan sampel pakan sapi untuk dianalisis kandungan nutrisinya. Uji kualitas bahan pakan (BK dan PK) telah dilakukan dengan menggunakan metode analis proksimat dan menghitung TDN dengan rumus Harris et al. (1972).

\section{Variabel yang Diamati}

Data yang diambili dalam penelitian ini adalah jenis, kandungan nutrisi dan konsumsi pakan, dan pertambahan bobot badan ternak untuk mengevaluasi kecukupan nutrisi pakan. Cara pengukuran variabel yang diamati adalah sebagai berikut:

1. Kandungan nutrisi pakan (bahan kering dan protein kasar) dianalisis dengan menggunakan metode analisis proksimat, sedangkan TDN dihitung dengan rumus Harris et al. (1972).: TDN = ($54.72+6.769 *$ SK-

$$
\begin{aligned}
& 51.083 * \mathrm{LK}+1.851 * \mathrm{ETN}- \\
& 0.034 * \mathrm{PK}- \\
& 0.049 * \mathrm{SK}^{\wedge 2}+3.38 * \mathrm{LK}^{\wedge 2}{ }_{-} \\
& 0.086 * \mathrm{SK}^{*} \mathrm{ETN}+0.942 * \mathrm{PK}- \\
& \left.0.112 * \mathrm{LK}^{\wedge}{ }^{\wedge} \mathrm{PK}\right)
\end{aligned}
$$


2. Konsumsi Pakan

a. Konsumsi Segar $(\mathrm{kg})=$ Jumlah pemberian - Sisa pakan

b. Konsumsi BK $(\mathrm{kg})=\%$ BK x Konsumsi Segar

c. c. Konsumsi PK $(\mathrm{kg})=\% \mathrm{PK} \mathrm{x}$ Konsumsi BK

d. Konsumsi $\operatorname{TDN}(\mathrm{kg})=\% \mathrm{TDN}$ $\mathrm{x}$ Konsumsi BK

e. Konsumsi pakan di padang penggembalaan diperoleh dengan cara menghitung selisih antara berat ternak sebelum dan sesudah digembalakan.

3. Pertambahan bobot badan harian dihitung dengan rumus :

PBBH $(\mathrm{kg})=\frac{\text { Bobot badan akhir-Bobot badan awal }}{\text { Lama }}$

4. Evaluasi kecukupan nutrisi dilakukan dengan membandingkan konsumsi pakan dengan kebutuhan ternak.

\section{Analisis data}

Data yang diperoleh dari hasil penelitian ini dianalisis secara deskriptif menggunakan paket program Microsoft Excel 2016.

\section{HASIL DAN PEMBAHASAN}

\section{Gambaran Umum Lokasi Penelitian}

Penelitian ini dilaksanakan di Balai Pembibitan Ternak dan Hijauan Makanan Ternak (BPT-HMT) Serading Sumbawa. BPT-HMT Serading merupakan salah satu lembaga di bawah Dinas Peternakan dan Kesehatan Hewan Provinsi Nusa Tenggara Barat yang mengelola sistem pembibitan ternak dan pemeliharaan hijauan makanan ternak. BPT-HMT Serading memiliki luas sekitar 42,52 Ha dengan jumlah ternak yang dipelihara sebanyak 184 ekor sapi Bali. Jumlah sapi Bali calon pejantan yang dipelihara sampai dengan bulan September 2020 adalah sebanyak 31 ekor. Lokasi ini terletak di Desa Serading Kecamatan Moyo Hilir Kabupaten Sumbawa. Kantor BPT-HMT Serading cukup mudah diakses karena berlokasi di jalan lintas Sumbawa-Bima yang hanya berjarak sekitar $9 \mathrm{~km}$ dari pusat kota Sumbawa.

\section{Sistem Pemeliharaan}

BPT-HMT Serading menerapkan sistem pemeliharaan sapi Bali calon pejantan secara Semi Intensif. Pada pagi hari ternak dilepas di padang penggembalaan selama 2-3 jam, kemudian dikembalikan lagi ke kandang. Mengingat durasi pemeliharaan di kandang jauh lebih lama daripada di padang penggembalaan, maka pakan utama dari sapi Bali calon pejantan tersebut masih mengandalkan pakan yang diberikan saat di kandang, yakni rumput raja, lamtoro, gamal dan jerami jagung. Pakan yang ada di padang penggembalaan hanya rumput bintang. Jenis dan jumlah pakan yang diberikan di kandang dan padang 
penggembalaan disajikan pada Tabel

1.

Tabel 1. Jenis, Jumlah Pemberian, Konsumsi dan Kandungan Nutrisi Pakan

\begin{tabular}{llcccccc}
\hline \multirow{2}{*}{ No } & \multirow{2}{*}{ Jenis Pakan } & \multicolumn{2}{c}{ Jumlah Pemberian } & \multicolumn{2}{c}{ Konsumsi } & \multicolumn{3}{c}{ Kandungan Nutrisi (\%) } \\
& & (kg/ekor/hari) & $\mathbf{( \% )}$ & (kg/ekor/hari) & BK & PK & TDN \\
\hline 1 & Rumput Raja & 2,32 & 25.47 & 2.17 & 23.74 & 8.37 & 56.22 \\
2 & Lamtoro & 1,97 & 21.62 & 1.62 & 27.42 & 17.09 & 71.14 \\
3 & Jerami Jagung & 1.90 & 20.86 & 1.75 & 55.07 & 4.85 & 57.78 \\
4 & Gamal & 1.17 & 12.84 & 1.02 & 18.13 & 20.45 & 64.89 \\
5 & Rumput Bintang & 1.75 & 19.21 & 1.75 & 37.21 & 10.23 & 56.95 \\
\hline & Total & 9.11 & 8.31 & & & \\
\hline
\end{tabular}

Sumber : Data diolah (2020).

Pemberian pakan untuk sapi

Bali calon pejantan pada saat dikandangkan bervariasi mulai dari jenis dan jumlah pakan. Hal ini disesuaikan dengan ketersediaan pakan yang ada. Rata-rata jumlah pemberian pakan sapi Bali jantan muda per ekor/hari adalah rumput raja sebanyak $2,32 \mathrm{~kg}(25.47 \%)$, lamtoro $1,97 \mathrm{~kg}(22.62 \%)$, jerami jagung 1,90 $\mathrm{kg}(20.86 \%)$ dan gamal $1,17 \mathrm{~kg}$ (12.84 \%) (Tabel 1). Sedangkan pakan yang ada di padang penggembalaan adalah rumput bintang sebanyak $1.75 \mathrm{~kg} /$ ekor/hari (19.21\%). Rata-rata jumlah pemberian pakan untuk sapi Bali jantan muda merupakan penjumlahan rata-rata pemberian pakan di kandang dan di padang penggembalaan yaitu sebanyak $\quad 9.11 \quad \mathrm{~kg} / \mathrm{ekor} / \mathrm{hari}$. Pemberian pakan kepada sapi jantan muda ini lebih rendah bila dibandingkan dengan pemberian pakan $10 \%$ dari bobot badan, yaitu 10 $\%$ dari $114 \mathrm{~kg}$ atau $11.4 \mathrm{~kg}$. Hal ini tidak sesuai dengan rata-rata pemberian pakan bagi sapi potong yaitu 10\% dari bobot badan (Sugeng, 2008).

\section{Kualitas Pakan}

Rumput Raja memiliki kualitas yang baik dibandingkan dengan jerami, namun ketersediaannya menjadi faktor utama. Berdasarkan Tabel 1, hasil analisis kandungan nutrisi rumput raja adalah BK 23.74 \%, PK $8.37 \%$ dan TDN 56.22\%. Umur pemotongan dan manajemen pemupukan menjadi salah satu faktor yang berpengaruh terhadap variasi kandungan nutrisi rumput raja (Wadi dkk.,2004). Faktor imbangan batang dan daun juga berpengaruh terhadap kandungan nutrisi, semakin tua rumput raja, batangnya semakin keras dan serat kasarnya semakin tinggi. Rumput raja mempunyai produksi yang lebih tinggi jika dibandingkan dengan rumput gajah yang didukung dengan kandungan zat gizi yang 
cukup baik, yaitu BK $12.18 \%$, PK $11.68 \%$ dan SK $32.49 \%$ (Siregar,1994).

\section{Konsumsi Pakan}

\section{Konsumsi Pakan Segar}

Rata-rata konsumsi pakan segar di kandang adalah rumput raja sebanyak 2.17;

lamtoro

1.62; jerami jagung 1.75 dan gamal $1.02 \mathrm{~kg} / \mathrm{ekor} /$ hari atau sejumlah 6.56 kg/ekor/hari. Karena sistem pemeliharaan sapi Bali calon pejantan menggunakan sistem semi intensif yaitu ternak dikandangkan dan digembalakan pada pagi hari dengan durasi sekitar 2-3 jam sehingga sapi Bali jantan muda mendapat tambahan pakan dari padang penggembalaan dengan rata-rata konsumsi 1.75 $\mathrm{kg}$ /ekor/hari. Jadi sapi Bali jantan muda mengonsumsi pakan sebanyak $8.31 \mathrm{~kg} / \mathrm{ekor} /$ hari (Tabel 1).

\section{Konsumsi Nutrisi}

Hasil perhitungan menunjukkan bahwa secara keseluruhan rata-rata konsumsi nutrisi (bahan kering, protein kasar dan TDN) belum memenuhi kebutuhan Sapi Bali calon pejantan (Tabel 2). Belum terpenuhinya nilai konsumsi nutrisi ini disebabkan oleh pemberian pakan yang kurang $10 \%$ dari bobot badan ternak. Pemberian pakan seharusnya $11,4 \mathrm{~kg}$, namun kenyataannya diberikan 9.11 $\mathrm{kg}$ /ekor/hari (Tabel 1). Hal ini disesuaikan dengan ketersediaan pakan yang ada di BPT-HMT Serading Sumbawa.

Tabel 2. Konsumsi, Kebutuhan, BB dan PBBH Sapi Bali JantanMuda di BPT-HMT Serading.

\begin{tabular}{|c|c|c|c|c|c|c|c|c|c|c|}
\hline $\begin{array}{l}\text { No } \\
\text { Sapi }\end{array}$ & $\begin{array}{l}\text { Bbo } \\
(\mathrm{kg})\end{array}$ & & $\begin{array}{l}\text { Konsur } \\
(\mathrm{kg})\end{array}$ & & & $\begin{array}{l}\text { Kebutu } \\
(\mathrm{kg})\end{array}$ & & $\begin{array}{l}\mathrm{Bbt} \\
(\mathrm{kg})\end{array}$ & $\begin{array}{l}\text { PBBH } \\
(\mathrm{kg})\end{array}$ & Keterangan \\
\hline & & BK & PK & TDN & BK & PK & TDN & & & \\
\hline 1 & 122 & 2.51 & 0.248 & 1.50 & 3.24 & 0.327 & 1.94 & 127.5 & 0.06 & Kon $<$ Keb. \\
\hline 2 & 105 & 2.57 & 0.255 & 1.54 & 2.90 & 0.273 & 1.74 & 110.5 & 0.06 & Kon $<$ Keb. \\
\hline 3 & 113 & 2.47 & 0.244 & 1.48 & 3.06 & 0.298 & 1.84 & 118.5 & 0.06 & Kon $<$ Keb. \\
\hline 4 & 107 & 2.47 & 0.244 & 1.48 & 3.14 & 0.296 & 1.88 & 116 & 0.10 & Kon $<$ Keb. \\
\hline 5 & 109 & 2.50 & 0.247 & 1.50 & 2.98 & 0.286 & 1.79 & 114.5 & 0.06 & Kon $<$ Keb. \\
\hline 6 & 130 & 2.56 & 0.254 & 1.53 & 4.01 & 0.407 & 2.40 & 146.5 & 0.18 & Kon $<$ Keb. \\
\hline 7 & 106 & 2.67 & 0.266 & 1.60 & 3.01 & 0.283 & 1.80 & 113 & 0.08 & Kon $<$ Keb. \\
\hline 8 & 115 & 2.50 & 0.247 & 1.50 & 3.21 & 0.315 & 1.93 & 122.5 & 0.08 & Kon $<$ Keb. \\
\hline 9 & 118 & 2.47 & 0.244 & 1.48 & 3.23 & 0.322 & 1.95 & 125 & 0.08 & Kon $<$ Keb. \\
\hline 10 & 116 & 2.90 & 0.278 & 1.72 & 3.15 & 0.311 & 1.89 & 122 & 0.07 & Kon $<$ Keb. \\
\hline Rerata & 114.1 & 2.51 & 0.253 & 1.53 & 3.19 & 0.311 & 1.92 & 121.6 & 0.08 & Kon $<$ Keb. \\
\hline
\end{tabular}

Sumber: Data diolah (2020). Keterangan: BBo:bobot badan awal, BB: bobot badan akhir,Keb.: kebutuhan,Kon.: konsumsi 


\section{Konsumsi Bahan Kering}

Rata-rata konsumsi bahan kering $2.51 \mathrm{~kg} / \mathrm{ekor} /$ hari, sedangkan rata-rata kebutuhan bahan keringnya $3.19 \mathrm{~kg} / \mathrm{ekor} /$ hari (Tabel 2). Menurut Tillman et al.(1991), kebutuhan bahan kering pakan yang disarankan untuk sapi pedaging adalah 3-4\% dari bobot badan. Tingginya konsumsi bahan kering dipengaruhi oleh beberapa faktor palatabilitas pakan diantaranya rasa, bentuk dan bau dari pakan itu sendiri (Tillman et al.,1991). Konsumsi bahan kering menurut Lubis (1992) dipengaruhi oleh beberapa faktor diantaranya: 1) faktor pakan yang meliputi daya cerna dan palatabilitas, dan 2) faktor ternak yang meliputi bangsa, jenis kelamin, umur, bobot badan dan kondisi kesehatan ternak. Menurut Zulbadri et al. (1995), peningkatan konsumsi bahan kering ransum akan diikuti oleh peningkatan protein kasar dan Total Digestible Nutrient (TDN), dan sebaliknya apabila terjadi penurunan konsumsi bahan kering, maka konsumsi PK dan TDN juga akan mengalami penurunan.

\section{Konsumsi Protein Kasar}

Berdasarkan data yang diperoleh bahwa rata-rata konsumsi protein kasar sebesar

$\mathrm{kg}$ /ekor/hari, sedangkan kebutuhannya $0.311 \mathrm{~kg}$ /ekor/hari (Tabel 2). Secara keseluruhan rata-rata konsumsi protein kasar belum memenuhi kebutuhan sapi Bali jantan calon pejantan. Hal ini disebabkan oleh kurangnya pemberian pakan yang mengandung protein tinggi. Menurut Kearl (1982), kebutuhan protein kasar untuk ternak sapi adalah $12-14 \%$ dari kebutuhan bahan kering. Protein merupakan senyawa organik kompleks yang mempunyai berat molekul tinggi. Ternak ruminansia mendapatkan protein dari tiga sumber, yaitu protein mikroba rumen, protein pakan yang lolos dari perombakan mikroba rumen dan sebagian kecil dari endogenus (Tillman et al., 1991).

Protein dapat diperoleh dari bahan-bahan pakan yang berasal dari tumbuh-tumbuhan dan biji-bijian (Sugeng, 2006). Protein di dalam tubuh ternak ruminansia dapat dibedakan menjadi protein yang dapat disintesis dan protein yang tidak dapat disintesis. Anggorodi menyatakan bahwa kekurangan protein pada sapi dapat menghambat pertumbuhan sapi, sebab fungsi protein adalah untuk memperbaiki jaringan, pertumbuhan jaringan baru, metabolisme, sumber energi, pembentukan anti bodi, enzim-enzim dan hormon. Protein juga berfungsi dalam sintesis enzim dan hormon yang diperlukan dalam proses spermatogenesis.

\section{Konsumsi TDN}

Berdasarkan hasil perhitungan diperoleh bahwa rata-rata konsumsi TDN sebesar $1.53 \mathrm{~kg} / \mathrm{ekor} / \mathrm{hari}$, sementara kebutuhan energi (TDN) sebesar $1.92 \mathrm{~kg} /$ ekor/hari (Tabel 2). 
Rata-rata konsumsi TDN belum dapat mencukupi kebutuhan sapi Bali calon pejantan. Hal ini disebabkan oleh kurangnya pemberian pakan yang mengandung TDN (Tabel 1). Kebutuhan energi pada sapi pejantan diperlukan dalam proses spermatogenesis dan sebagai sumber energi bagi spermatozoa. Pada sapi jantan, kekurangan konsumsi energi akan menyebabkan pertumbuhan dan reproduksi yang terlambat terutama dalam produksi spermatozoa, ukuran lingkar skrotum dan kualitas semen. Salah satu faktor yang berpengaruh terhadap performans sapi jantan adalah pakan. Pemberian pakan harus optimal dan dapat mendukung performans sapi jantan. Kelebihan atau kekurangan energi dapat berdampak negatif terhadap kualitas semen dan proses spermatogenesis.

Nutrisi sangat penting selama perkembangan sistem reproduksi sapi jantan muda. Meningkatkan jumlah nutrisi akan mempercepat pubertas dan pertumbuhan tubuh (Sprott et al., 1998). Makanan berpengaruh terhadap ukuran testis pada ternak jantan. Makanan yang diberikan terlalu sedikit terutama pada periode sebelum masa pubertas dicapai dapat menyebabkan perkembangan testis dan kelenjar-kelenjar asesoris terhambat dan dapat memperlambat dewasa kelamin dan berpengaruh terhadap produksi spermatozoa.

\section{Pertambahan Bobot Badan Harian}

Pertambahan bobot badan adalah kemampuan ternak untuk mengubah zat-zat nutrisi yang terdapat dalam pakan menjadi daging. Pertambahan bobot badan ternak ruminansia sangat dipengaruhi oleh kualitas dan kuantitas pakan, maksudnya penilaian pertambahan bobot badan ternak sebanding dengan ransum yang dikonsumsi. Untuk memperoleh pertambahan bobot badan harian maka perlu dilakukan penimbangan pada ternak. Setelah melakukan penimbangan dan perhitungan maka didapatkan rata-rata pertambahan bobot badan harian sapi Bali calon pejantan sebesar 0,08 kg (Tabel 2).

Pertamabahan bobot badan harian yang diperoleh dalam penelitian ini adalah sangat kecil yaitu $0,08 \mathrm{~kg} / \mathrm{ekor} / \mathrm{hari}$. Hal ini disebabkan oleh jumlah nutrisi yang dikonsumsi oleh sapi Bali jantan muda belum dapat memenuhi kebutuhan berdasarkan bobot badan ternak (Tabel 2). Parakkasi menyatakan bahwa pertambahan bobot badan dipengaruhi oleh konsumsi BK, PK dan TDN pakan. Pertambahan bobot badan terjadi apabila ternak mampu mengubah zatzat nutrisi yang diperoleh menjadi produk ternak seperti lemak dan daging setelah kebutuhan pokok terpenuhi (Williamson dan Payne, 1993). 


\section{KESIMPULAN DAN SARAN}

\section{Kesimpulan}

Kesimpulan yang dapat diambil dari hasil penelitian ini adalah bahwa nutrisi yang dikonsumsi oleh sapi Bali jantan muda yang dipelihara di BPTHMT Serading Sumbawa belum cukup untuk memenuhi kebutuhan ternak. Konsumsi bahan kering 2.56 $\mathrm{kg}$ /ekor/hari, sedangkan kebutuhannya $3.19 \mathrm{~kg} / \mathrm{ekor} / \mathrm{hari}$; konsumsi protein kasar 0.253 $\mathrm{kg} / \mathrm{ekor} / \mathrm{hari}$ sedangkan kebutuhannya $0.331 \mathrm{~kg} / \mathrm{ekor} / \mathrm{hari}$; dan konsumsi TDN $1.53 \mathrm{~kg} / \mathrm{ekor} / \mathrm{hari}$, sedangkan kebutuhannya 1.93 kg/ekor/hari. Akibatnya, pertumbuhan ternak menjadi sangat lambat (pertambahan bobot badan harian hanya $0.08 \mathrm{~kg} / \mathrm{ekor} /$ hari).

\section{Saran}

Jumlah pakan yang dikonsumsi belum cukup untuk memenuhi kebutuhan ternak, hal ini disebabkan oleh kurangnya ketersediaan pakan. Disarankan untuk memperhatikan tentang kualitas dan kuantitas pakan yang diberikan kepada ternak, menerapkan teknologi silase dan teknologi fermentasi untuk persediaan cadangan pakan di musim kemarau.

\section{DAFTAR PUSTAKA}

Anggorodi, R. 1994. Ilmu Makanan Ternak Umum. PT. Gramedia Pustaka Utama, Jakarta.
Askar, S. 1997. Nilai Gizi Daun Lamtoro dan Pemanfaatannya Sebagai Pakan Ternak Ruminansia. Balai Penelitian Ternak Ciawi. Bogor.

Aye PA and Adegun MK. 2013. Chemical Composition and SomeFunctional Properties of Moringa, Leucaena and Gliricidia Leaf Meals. Agriculture and Biology Journal of North America.4(1). 71-77.

Harris, L.E., Kearl, L.C., and Fonnesbeck, P.V.,1972. Use of Regression Equations in Predicting Availability of Energy and Protein.

Hartadi, H., S. Reksohadiprodjo dan A.D. Tillman. 1997. Tabel Komposisi Pakan Untuk Indonesia. Cetakan III. Gadjah Mada University Press, Yogyakarta.

Kearl, L.C. 1982. Nutrient Requirements of Ruminants in Developing Countries. International Feedstuffs Institute Utah Agricultural Experiment Station Utah State University, Logan Utah.

Leng, R.A. 1991. Aplication of Biotechnology to Nutrition of Animal in Developing Countries. Rome: Animal Production and Health Paper, FAO. 
Lubis, D. A, 1992. Ilmu Makanan Ternak. PT. Pembangunan, Jakarta.

Mayulu, H. dan Suhardi,S. 2015. Nutrient Potency of Rice Straw Processed with Amofer as Cattle Feedstuff in East Kalimantan. International Journal of Science and Engineering, 9(2), 101105.https:doi.org/10.12777/IJS E.9.2.101-105.

Natalia, H., D. Nista, dan S. Hindrawati. 2009. Keunggulan Gamal Sebagai Pakan Ternak. BPTU Sembawa, Palembang.

Parakkasi, A. 1999. Ilmu Nutrisi dan Makanan Ternak Ruminan. Universitas Indonesia Press, Jakarta.

Parkinson, T. J. 2004. Review: Evaluation of Fertility and Infertility in Natural Service Bulls. Vet . J. 168:215-229.

Reksohadiprodjo S. 1994. Produksi Tanaman Hijauan Makanan Ternak Tropik. BPFE, Yogyakarta.

Santosa. U. 2002. Tata Laksana Pemeliharaan Ternak Sapi. Penebar Swadaya. Jakarta.

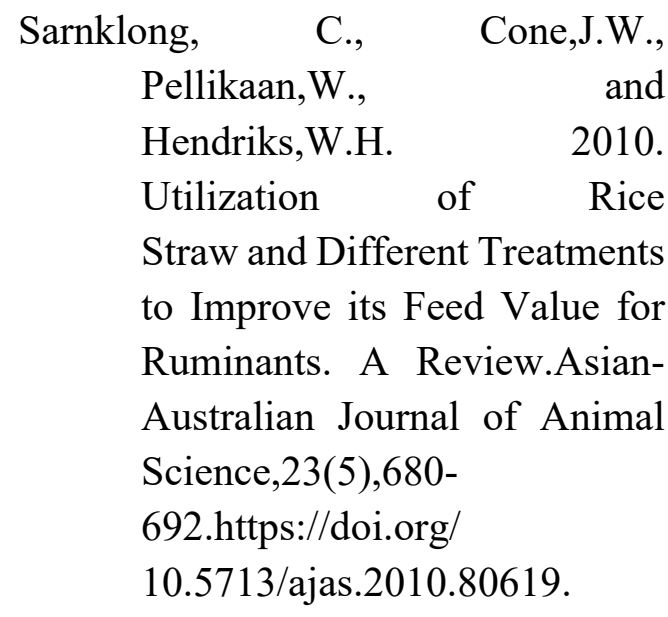

Siregar, S. B. 1994. Ransum Ternak Ruminansia. Penebar Swadaya. Jakarta.

Sprott, L. R., T. A. Thrift and B.B Carpenter. 1998. Breeding Soundness of Bulls. Agricultural Comunications. The Texas A and M University System.

Sugeng, Y. B. 2006. Sapi Potong. Penebar Swadaya, Jakarta.

Tillman, A. D. 1991. Komposisi Bahan Makanan Ternak Untuk Indonesia. Gadjah Mada University Press, Yogyakarta.

Wadi, A., Ishii, Y., and Idota, S. 2004. Effects of Cutting Interval and Cutting Height on Dry Matter Yield and Overwintering Ability at the Established Year in Pennisetum species. Plant Production Science, 7(1),8896.https:doi.org/10.1626/pps.7 .88 . 
Wijono, 1992. Ilmu Peternakan.

Terjemahan.Universitas

Gadjah Mada Press.

Yogyakarta.

Williamson, G. and W.J.A. Payne.

1993. Pengantar Peternakan di

Daerah Tropis. Cetakan I.

Gadjah Mada University Press, Yogyakarta.

Zulbadri, M., P. Sitorus, Maryono dan Affandy, L., 1995. Potensi dan Pemanfaatan Pakan Ternak di Daerah Sulit Pakan. Kumpulan Hail-hasil Penelitian APBN T.A. 1994/1995. Balai Penelitian Ternak Ciawi, Bogor. 